\title{
Elemzési szempontrendszer terminológiai adatbázisokhoz ${ }^{1}$
}

\author{
Tamás Dóra Mária \\ E-mail: tamas.dora.maria@gmail.com \\ Sermann Eszter \\ E-mail: eszter.sermann.lingo@gmail.com
}

\begin{abstract}
Kivonat: A tanulmány célja egy olyan vizsgálati és minősítési szempontrendszer megalkotása, amely alapján objektív szempontok szerint leírhatóvá, értékelhetővé válnak az online elérhetőségü nagy központi adatbázisok. A jelen kutatás alapját a hazai és a nemzetközi szakirodalom tanulmányozása, konkrét példák elemzése, egyéb adatbázis-osztályozási rendszerek egyes elemeinek alkalmazása, valamint a szerzők korábbi kutatásai képezik. A terminológiai szakirodalomban fellelhető a terminológiai adatbázisok definiálása, jellemzőik összevetése az elektronikus szótárakkal, konkrét adatbázisok leírása, valamint születtek különböző osztályozások, szempontrendszerek is, amelyek azonban nem alkalmasak az átfogó elemzéshez és recenzáláshoz. A tanulmányban az általunk kidolgozott rendszer alapján elemezzük az IATE adatbázist, az Európai Unió intézményeinek terminológiai adatbázisát. Úgy véljük, hogy ezek a szempontok segítségül szolgálhatnak a terminológiai adatbázisok tudatos használatához, a hozzájuk kapcsolódó ismeretek elmélyítéséhez, valamint támpontot nyújthatnak olyan hatékony segédeszközök kidolgozásához, melyek gördülékennyé teszik a szakmai kommunikációt. Segíthetnek abban is, hogy objektív szakmai véleményt lehessen kialakítani és közölni a terminológiai adatbázisokról, akár szóbeli, akár recenzió formájában, és reményeink szerint átfogó jellegével e szempontrendszer még fejlesztési ötleteket is inspirálhat.
\end{abstract}

Kulcsszavak: fordítói segédeszközök, terminológiai adatbázis, értékelési rendszer, általános jellemzők, technikai paraméterek

\footnotetext{
${ }^{1}$ A jelen tanulmány kibővített változata $A$ vizsgálati szempontrendszer online terminológiai adatbázisokhoz c. közlésre elfogadott tanulmánynak (Sermann és Tamás 2020), valamint átdolgozott változata az Evaluation system for online terminological databases címü angol nyelven közlésre elfogadott tanulmánynak (Tamás és Sermann 2019).
}

Hivatkozás: Tamás D. M., Sermann E. 2019. Elemzési szempontrendszer terminológiai adatbázisokhoz. Fordítástudomány 21. évf. 2. szám. 46-62.

DOI: https://doi.org/10.35924/fordtud.21.2.4 


\section{Bevezetés}

$\mathrm{Az}$ online terminológiai adatbázisok mára hatékony és szinte elengedhetetlen segédeszközzé váltak a helyes szakmai kommunikációs és terminushasználat megvalósulása érdekében. Az adatbázis müfajként a terminológia mint alkalmazott nyelvészeti diszciplína területéhez tartozik, szerkesztésmódjában és tartalmában egyedi jellemzőket mutat. A hármas értelmezésben használt terminológia (elmélet, módszertan és szógyüjtemény) központi kategóriája a fogalom, és ebből következően fogalomközpontú szemléletmódot követ (Bessé et al. 1997, Fóris 2005). Ez tükröződik a terminológia mindhárom területén: visszaköszön az elméleti kutatásokban; megtalálhatjuk a módszertanban a terminusok elemzésekor a fogalmi összehasonlítás folyamatában; s az adatok, szógyüjtemények rendezésében a terminológiai adatbázisokban (Tamás 2018).

Bár létezik számos közös jellemzőjük, mégis mivel más-más konkrét célok megvalósítása érdekében hozzák ezeket létre (nyelvpolitikai célok, vállalati megbízásból vagy nemzetközi szervezetek munkája nyomán), és más-más típusú fogalmakat dolgoznak fel (jogi, gazdasági, orvosi stb.) különböző részletességgel, rögtön láthatjuk, hogy számos pontban különböznek egymástól. Éppen ezért nehézkes egy átfogó, valamennyi szempontra kiterjedő egységesen elfogadott szempontrendszer megalkotása.

A tanulmány célja a szakirodalmi előzmények alapján egy olyan lehetséges, kísérleti jellegű vizsgálati és minősítési szempontrendszer megalkotása, amely alapján viszonylag objektív és átfogó szempontok szerint értékelhetővé válnak az online elérhetőségű nagy központi adatbázisok. A vizsgálati szempontrendszer alapját képezik a nyomtatott és az elektronikus szótárak már kidolgozott minősítési szempontrendszerei (Fóris és Rihmer 2007, Gaál 2012). A szótárak a szerkesztési elveket és a felhasználói felületet tekintve is eltérő megközelítést tükröznek, ezért a terminológiai adatbázisok vizsgálata és minősítése új szempontrendszer kidolgozását kívánja meg. A tanulmány végén az általunk kidolgozott szempontok alapján elemezzük az IATE, az Európai Unió intézményeinek egyesített intézményközi adatbázisát.

\section{Szakirodalmi előzmények}

A vizsgálati szempontrendszerünk kiindulópontjaként korábbi kutatásaink során megalkottuk a terminológiai adatbázisoknak vizsgálatunk szempontjából releváns definícióját, mely szerint „a terminológiai adatbázis olyan elektronikusan tárolt terminológiai adatok összessége, amely onomasziológiai szemléletet követve készült, megalkotásának előfeltétele az adott szakterület fogalmi rendszerének felvázolása. Egy vagy több szakterület terminusait és a hozzájuk tartozó definíciókat tartalmazza egy vagy több nyelven" (Sermann és Tamás 2010: 113). Összevetettük a terminológiai adatbázisok jellemzőit az elektronikus szótárak jellemzőivel (Sermann és Tamás 2010), és megállapítottuk, hogy az elektronikus szótárak és a terminológiai adatbázisok azonos és eltérő jegyekkel 
egyaránt rendelkeznek, az alapvető különbségeket összefoglaltuk (lásd 1. táblázat).

\section{1. táblázat}

Összefoglaló táblázat az online elektronikus szótár és a terminológiai adatbázis jellemzöinek összehasonlitásáról

(Tamás 2014: 139, Sermann és Tamás 2013 nyomán)

\begin{tabular}{|l|l|}
\hline \multicolumn{1}{|c|}{ Online elektronikus szótár } & \multicolumn{1}{|c|}{ Terminológiai adatbázis } \\
\hline szemasziológiai elvek & onomasziológiai elvek \\
\hline központi eleme: a szó & $\begin{array}{l}\text { központi eleme: a terminus által jelölt és } \\
\text { a definícióban megjelenő fogalom }\end{array}$ \\
\hline jelentéseket sorol fel & $\begin{array}{l}\text { az adatokat a fogalomhoz (definícióhoz) } \\
\text { rendeli hozzá }\end{array}$ \\
\hline $\begin{array}{l}\text { többletinformációk: } \\
\text { pl. kiejtés (hangszóró ikon), } \\
\text { kontextusszótárból kiválasztott } \\
\text { példamondatok }\end{array}$ & $\begin{array}{l}\text { többletinformációk: } \\
\text { információk: az ekvivalenciaszintről (teljes, } \\
\text { részleges ekvivalencia vagy ekvivalencia } \\
\text { hiánya), a megadott ekvivalensröl (terminus, } \\
\text { funkcionális ekvivalens vagy terminusjelölt; } \\
\text { címkék mint szabványosított, harmonizált, } \\
\text { ajánlott stb.) }\end{array}$ \\
\hline
\end{tabular}

A nyomtatott szótárakra vonatkozó szempontrendszerek (Fóris és Rihmer 2007, Fóris 2018) egyebek mellett kiterjednek a szótárral kapcsolatos háttérinformációkra, a tartalomra vonatkozó információkra (mega-, makro-, mikroés mezostruktúra), a tartalmi elemekre (lexikológiai alapok, nyelvészeti információk), valamint a szótár használatára vonatkozó adatokra. A megastruktúra alatt az előszó, használati útmutató, tárgymutató és bibliográfia megléte vagy hiánya, a makrostruktúra alatt a szócikkek szerveződési elvei (pl. alfabetikus vagy tematikus), a mikrostrúktúra alatt az egyes szócikkek tagolódása, míg a mezostruktúra alatt az utalási rendszer értendő.

Az elektronikus szótárakra alkalmazható szempontrendszer (Gaál 2012) a segédeszköz jellegéből adódóan egyéb elemekkel is kiegészül, mint a szótár technikai paraméterei, beágyazottsága, valamint a szerkezeti szempontokon belül a keresőmotor jellemzése és a keresési találatok megjelenítése.

A terminológiai adatbázisok esetében megtörtént továbbá konkrét adatbázisok leírása (Tamás 2010, 2014, Sermann 2011, 2019, Novák 2018), valamint születtek különböző osztályozások, szempontrendszerek (Sager 1990, Arntz et al. 2014, Tamás 2014, Schmitz és Drewer 2017), amelyek azonban nem alkalmasak az átfogó elemzéshez az oktatásban és a szakfordítók ismeretének bővítéséhez, továbbá recenziók készítéséhez. A jelen tanulmányhoz az alábbi adatbázis-osztályozási rendszert használtuk fel (lásd 2. táblázat). 


\section{2. táblázat}

A terminológiai adatbázisok típusainak kísérleti osztályozása

(Tamás 2014: 111 nyomán)

\begin{tabular}{|l|l|l|l|}
\hline $\begin{array}{c}\text { Terminológiai } \\
\text { adatbázis típusa }\end{array}$ & \multicolumn{1}{|c|}{$\begin{array}{c}\text { Fogalom- } \\
\text { központúság }\end{array}$} & $\begin{array}{c}\text { Terminus- } \\
\text { autonómia }\end{array}$ & \multicolumn{1}{c|}{$\begin{array}{c}\text { Adatmezók } \\
\text { mennyisége }\end{array}$} \\
\hline EGYSZERÜ & érvényesül & $\begin{array}{l}\text { nem feltétlenül } \\
\text { érvényesül } \\
\text { (szólista jelleg) }\end{array}$ & $\begin{array}{l}\text { és/vagy } \\
\text { számuk nem éri el a min. } \\
\text { mennyiséget (pl. csak } \\
\text { terminus és tárgykör) }\end{array}$ \\
\hline HAGYOMÁNYOS & érvényesül & érvényesül & $\begin{array}{l}\text { min. elvárható számú } \\
\text { adatmezó szerepel, } \\
\text { definíció legalább egy } \\
\text { nyelven }\end{array}$ \\
\hline $\begin{array}{l}\text { ÖSSZETETT } \\
\text { tudásbázis és } \\
\text { terminológiai } \\
\text { információs } \\
\text { rendszer }\end{array}$ & érvényesül & érvényesül & $\begin{array}{l}\text { min. elvárható számú } \\
\text { adatmező szerepel, plusz } \\
\text { további ismeretelemek } \\
\text { (szövegkorpusz, fogalmi } \\
\text { háló) }\end{array}$ \\
\hline
\end{tabular}

A fenti osztályozás szerint az egyszerü adatbázisok csoportjába sorolható a Termin adatbázis a magyarországi Igazságügyi Minisztérium terminológiai adatbázisa, amely négy nyelven tartalmaz bejegyzéseket (magyar, angol francia, német), egyszerü táblázatos jellegü, a doménről és aldoménről tartalmaz információkat, esetlegesen a közelmúltban kiegészült magyarázatokkal (ezen belül: forrás, definíció, példamondat), de nem ad meg ennél több adatmező-kategóriát, bár az utóbbi időben ún. magyarázatokkal bővült, amelyek definíciót vagy kontextust tartalmaznak. Továbbá a bejegyzések (entry) a terminusautonómia szempontjából nem jelölik a fő terminust, csupán egy változatot szerepeltetnek.

A hagyományos típusú terminológiai adatbázisok között megemlíthető a bistro (Novák 2013, Tamás 2013), a Bolzano autonóm megye által kezdeményezett és az EURAC Research kutatóközpont által kialakított és fenntartott olasz, német és ladin jogi és közigazgatási terminológiai adatbázis. A bejegyzések részletesen kidolgozottak, számos adatmező-kategóriát tartalmaznak, legalább egy nyelven megadják a terminus definícióját, kereséskor a találati lista alapján elkülönítve mutatják be az egyes fogalmakat. Az összetett terminológiai adatbázisok között említhetjük meg a fogalmi hálókat vagy szövegkorpuszokat is tartalmazó terminológiai adatbázisokat. A fogalmi háló alkalmazására kiváló példa a WIPO Pearl, amely az ENSZ szervei közé tartozó Szellemi Tulajdon Világszervezetének terminológiai adatbázisa. Tíz nyelven tartalmaz adatokat és a nyelvi keresés mellett fogalmi hálók alapján is lehetővé teszi a terminusok felkutatását.

A vizsgálati szempontrendszer kialakításához az alábbi adatbázisokat elemeztük részletesen: bistro, DINTerm, Cercaterm, Evronim, EOHS Term, EUSKALTERM, France Terme, IATE, SAPTerm, Termdat, Termium Plus, 
Verwaltungsglossar, WIPO Pearl, Termin, UNTERM. Fontos hangsúlyozni, hogy a jelen vizsgálati szempontrendszer a központi, online terminológiai adatbázisok felhasználói felületére terjed ki, nem foglalja magában a terminológusok által készített terminológiai adatbankok (Bowker 2015: 307), egyéni, fájl- vagy szerveralapú terminológiai adatbázisok vizsgálatát, ezek elkészítéséhez szükséges munkafolyamatok leírását, elemzését, komplex terminológiamenedzsment rendszerek leírását (Arntz et al. 2014, Drewer et al. 2014, Schmitz és Drewer 2017). Az utóbbi szerzők a mindennapi használat igényeiből indultak ki, a vizsgálati szempontokat kevésbé általánosították kutatási célból.

\section{Vizsgálati szempontrendszer online terminológiai adatbázisokhoz}

\subsection{A központi terminológiai adatbázissal kapcsolatos háttér- információk}

Az adatbázishoz kapcsolódó tágabb háttér vizsgálatának kiindulópontjául az adott domén fellelhető terminológiai adatbázisainak áttekintése szolgál. $\mathrm{Az}$ esetleges korábbi változatok feltérképezésének nyomán képet kaphatunk arról, hogy milyen történeti előzményekkel rendelkezik a vizsgált adatbázis, illetve arról, hogy továbbfejlesztett adatbázisról van-e szó (például EURODICAUTOM és az IATE viszonya).

Vizsgálható továbbá, hogy létezik-e a terminológiai adatbázisnak kapcsolata más terminológiai adatbázisokkal: szervezeti háttér, adatok átvétele a szervezeten belül, alközpontok (lásd az IATE mint intézményközi adatbázis; Termdat mint a központi Svájci Kancellária és a kantonok adatbázisa, UNTERM mint az ENSZ és segédszervezeti adatbázisa).

Szintén a tágabb háttér leírásának része lehet az adatbázis irányzatok szerinti besorolása. Egyes esetekben az adatbázisok nyelvpolitikai célok megvalósításának céljából állami irányítás mellett születnek (például bistro, Termdat, TermiumPlus, TermCat), más esetekben hatékony fordítói segédeszköz megalkotása a cél fordítói terminológiai adatbázis formájában (például IATE), vagy éppen a szabványosítási folyamat során keletkezett terminusokat teszik nyilvánosan elérhetővé (például DINTerm). Gyakran e célok keverednek is egymással, egyszerre szolgál ki az adatbázis többféle célt.

A terminológiai adatbázis szűkebb hátterének leírásában sorra vehetjük az adatbázis-előállító szervezet jellemzőit: a szervezet típusát, hátterét, országos vagy nemzetközi érdekeltségét, a szakmai tárgyköröket, a rendelkezésre álló anyagi forrásokat. Megvizsgálhatjuk, hogy az adatbázist elóállító szervezet besorolható-e a tipikus adatbázis-elóállítói csoportok egyikébe (Tamás 2019a: 267):

- nemzetközi szervezetek (ENSZ - UNTERM, ENSZ WIPO - Wipo Pearl, EU - IATE, Eurotermbank);

- közigazgatási szervek (Svájci Közigazgatási Kancellária - Termdat, Igazságügyi Minisztérium - Termin); 
- kutatóintézetek és egyetemek (EURAC Research - bistro);

- fordítóirodák (Kanadai Központi Fordítóiroda - TermiumPlus).

További lépésként megvizsgálhatjuk, hogy milyen célcsoport számára készült az adatbázis (anyanyelvi beszélők számára, többségi vagy kisebbségi státuszú nyelvhasználók, fordítók vagy pedig egy adott szakma képviselői számára, pl. mérnök, jogász, orvos stb.).

Az adatbázis felhasználási céljának szempontjából beszélhetünk továbbá informatív jellegű leíró vagy normatív jellegü előíró típusról (Tamás 2019b: 110).

\subsection{A terminológiai adatbázis technikai paraméterei}

A technikai paraméterek között fellelhetünk olyanokat, amelyek a külső szemlélő, azaz az online felület felhasználója számára is könnyen hozzáférhetők, míg léteznek olyan jellemzők, amelyekhez az adatbázis belső felületének, létrejöttének hátteréről szóló ismereteket igényelnek. A belső szerkezet ismeretének függvényében írható le, hogy az adatbázis megfelel-e a terminológiai szemléletmód szerint hierarchikus hármas felépítésnek (bejegyzés-nyelvi indexálás-terminus szintje), esetleg szerkezetét tekintve adatbázis-hálózat, egyszerű adatbázis vagy relációs adatbázissal állunk szemben (Sermann és Tamás 2010). Szintén háttérinformációk szükségesek ahhoz, hogy megtudjuk, milyen mértékben hozzáférhető az adatbázis teljes adatállománya, illetve hogy egy vagy több adatállományban és milyen módon tárolják a nyelvi adatokat.

$\mathrm{Az}$ online központi adatbázisok általában külön e célra kifejlesztett vizualizációs felülettel rendelkeznek. Léteznek ugyanakkor hibrid megoldások, mint például a dél-tiroli bistro terminológiai adatbázis esete, amelyben a vizualizációs felület mögött lekérhetők az SDL Multiterm Trados szoftverben tárolt részletesebb adatok is. A Bécsi Egyetem közremüködésével készült, kb. 700 terminust tartalmazó Verwaltungsglossar idén már Excel-, TBX-, pdf-formátumban és SDL Trados Multiterm fájl formátumban és online hozzáférésű Quick Term szoftverrel, sőt applikációként is elérhető. Az egyre modernebb és technológiai szempontból fejlettebb változatoknál figyelmet fordítanak arra is, hogy a felhasználó számára a különböző futtatási platformokon lehetővé tegyék az adatokhoz való hozzáférést, így például okostelefon vagy táblagépek használatával (https://www.wipo.int/reference/en/wipopearl/news/2019/news_0003.html).

\subsection{A terminológiai adatbázis tartalmáról szóló információk}

\subsubsection{Az adatbázis általános jellemzöi}

A terminológiai adatbázisok általános jellemzőinek vizsgálatához két csoportba helyezve elemeztük a terminológiai szemléletmód érvényesülését és az adatbázisok szerkezetét: külön az átfogóbb, általánosabb és külön a részletekbe menő jellemzőket.

Az első csoportban elsőként az általános, főbb jellemzők közül azt vizsgáltuk, hogy az adatbázis nyelvi adatait valóban a fogalomközpontú szemléletmó- 
dot követve dolgozták-e ki. Előfordulhat ugyanis, hogy az adatbázis készítésekor a szemasziológiai (szó vagy más néven nyelvi-jel alapú) szerkesztési szemléletmód keveredik a fogalomközpontú megközelítéssel, és így például a terminusautonómia sem érvényesül (lásd szólista jelleg a Termium Plus esetében vagy szótárlisták SAPTerm adatbázis honlapján) (lásd még Sermann és Tamás 2013, Tamás 2015). A fentiek alapján beszélhetünk kizárólag onomasziológiai vagy szemasziológiai elemeket is tartalmazó terminológiai adatbázisokról.

$\mathrm{Az}$ általános jellemzőknél maradva a másik csoportba a tanulmány 2 . fejezet 2. táblázata alapján az terminológiai adatbázisokat a szerkezetük és a bejegyzések kifejtettsége szerint három alcsoportra osztottuk fel: egyszerü, a részletes kidolgozottságú hagyományos és a plusz ismeretelemeket mint szövegkorpuszt vagy fogalmi hálókat tartalmazó összetett terminológiai adatbázisok.

\subsubsection{A terminológiai adatbázisok szerkezetének részletes elemzése}

$\mathrm{Az}$ adatbázisok szerkezetének részletes vizsgálata több alcsoportra bontható. Ezeket kísérleti jelleggel megfeleltettük a nyomtatott szótárak kategorizálásának (Fóris és Rihmer 2007, Fóris 2018), és összevetettük, hogy mi egyenértékü a mega-, a makro-, a mikro- és a mezostruktúra szintjével a terminológiai adatbázisokban.

Ennek megfelelően a megastruktúra szintjén megvizsgálható, hogy találunk-e a terminológiai adatbázis használatáról szóló információkat, így használati útmutatót, súgót, gyakran ismételt kérdéseket, ismertetőt a terminológiai adatbázis céljáról, a szakterületről, a célcsoportról, a kidolgozási módról, a nyelvek, domének és aldomének, terminusok számáról vagy egyéb tájékozódást szolgáló segédleteket, mint fórum vagy chat-szolgáltatás elakadás esetén (lásd SAPTerm: chat, SAP Community, SAP Help Portal).

Az adatbázisok közlik a szerzői jogi védelemről szóló információkat is. A terminológiai adatbázisok felülete gyüjteményes műnek minősül, így szerzői jogvédelem alatt áll, kifejezetten védett az eredeti jellegű struktúra, az elrendezés módja, így az adatbázisok képernyőképe sem szabadon másolható vagy tehető közzé.

A makrostruktúra szintjén elemezhetők a terminológiai adatbázis által felkínált keresési módok: egyszerü, összetett; ez utóbbin belül terminusok, domén és aldomén szerint, szórészlet alapján, továbbá a nyelvi keresés kiegészülhet fogalmi háló alapján (lásd WIPO Pearl) vagy szövegkorpuszban történő kereséssel. Az adatbázisok kínálhatnak különböző előzetes szürési lehetőségeket, mint pl. a bistro esetében rákereshetünk az egyes jogágakra, nyelvekre és földrajzi használatra (lásd németországi, osztrák vagy svájci német alapján). Az adatbázis felkínálhatja továbbá a keresési módok elmentésének lehetőségét is, illetve előnyt jelenthet a nyelvfelismerés beépítettsége.

A keresés eredményeképpen a legtöbb adatbázis találati listát kínál fel (lásd a Termium Plus esetében nem találunk listát), és megvizsgálható ezen belül a keresési találatok megjelenítése módja, rendezettsége. Már ekkor információt kaphatunk a közölt anyag jellegéről: kizárólag szöveges vagy képi, multimédiás információk is szerepelnek benne. Esetleg keresési lehetőséget biztosít a Google 
ábrái között (lásd WIPO Pearl). Előfordulhat, hogy átjárást biztosít más adatállományba (például IATE és EURLEX jogszabálytár, WIPO Pearl és Patenscope szabadalmi adattár).

A mikrostruktúra szintjén az adatmező-kategóriák száma azonnal információt szolgáltat az adatbázis kidolgozottságának részletességéről. Képet kapunk arról, hogy minimális információkat tartalmaz-e vagy egy alaposan kidolgozott, részletezett adatállománnyal állunk szemben, amely mérlegelési lehetőséget biztosít a felhasználónak.

$\mathrm{Az}$ adatmező-típusokat vizsgálva szerkesztési szempontból megkülönböztethetők kötelező és fakultatív adatmező-típusok. Mindig fontos kérdés, hogy a definíció helyettesíthető-e például kontextussal.

Annak megállapítása érdekében, hogy a szerkesztési elveknek megfelelően melyek a terminus mellett a legfontosabb adatmező-típusok a szakirodalomra, a szabványokra, a bevált gyakorlatra (lásd Drewer et al. 2014) támaszkodhatunk és figyelembe vehetjük a meglévő terminológiai adatbázisokat (pl. hierarchikus elrendezési mód - bejegyzés, nyelvi indexálás és terminus szint betartása és annak lehetséges vizsgálata, lásd bővebben: Drewer et al. 2014). Arntz et al. (2009:233) szerint például az egyszerü adatbázis adatai: szakterület, nyelv, azonosító szám és egyéb kódok, terminus, nyelvtani jellemzők, definíció, kontextus, megjegyzés, szinonima, szerkesztő adatai, dátum, forrás. Arntz et al (2014: 229-238) már a mai terminológiamenedzsment igényeinek megfelelő komplexebb leírást tartalmaz.

Kétség kívül megállapíthatjuk, hogy a fogalomközpontúság miatt központi helyet foglal el a definíció. Az ekvivalencia nem mindig szerepel külön kategóriaként, emellett gyakori adatmező-típusok az alábbiak:

- terminus státusza (fó terminus, azaz main term or head term, szinonimák külön bejegyzésben vagy sem) és a reláció típusa a kapcsolódó terminusokkal (alá-, fölé- és mellérendeltsége);

- megbízhatóság és validált státusz jelölése;

- különböző címkék használata: földrajzi behatárolás; dokumentumtípus (pl. útlevél lásd Termium Plus); a szövetségi és a kantonális bejegyzéseket „zászló” jelzi (Termdat); elfogadottság (ajánlott, elfogadható, tiltott, szabványosított); a terminológiai bizottság által jóváhagyott (lásd bistro); archaikus használat (lásd IATE: obsolete);

- ábrák és egyéb multimédiás tartalmak;

- nyelvtani jellemzők;

- kollokációk.

A szerkesztési elvek betartásánál nem kizárólag a fogalomközpontúság és terminusautonómia vizsgálható, hanem olyan szempontok is, mint az elementaritás (egy adatmezőben egy adat szerepeltetése), a granularitás (az adatok kidolgozottságának mértéke legyen megfelelő a túl sok alkategória elkerülése érdekében) (Reinke 2012: 102, Arntz et al 2014: 239-241).

Ahogyan a terminológiában mint diszciplínában is különböző munkamódszereket és irányzatokat figyelhetünk meg, az adatbázisok felhasználói felületén 
is tükröződnek a különböző megközelítési módok. A munkamódszerek szerint a definíciók megjelenthetnek egy nyelven vagy több nyelven is. Lehetséges, hogy minden nyelven ugyanazt a fogalmat határozzák meg (lásd egységesen értelmezett uniós vagy nemzetközi fogalmak), ilyenkor egy nyelven is elegendő a definíció rögzítése, de az is lehetséges, hogy a kontrasztív egybevetés eredményeit hivatottak kiemelni. Az irányzatok szerint más-más adatmező-típus lehet hangsúlyos, például a szabványosítás esetében (lásd DINTerm) a szabványokra utalás, az egységesítés és harmonizáció vagy a fordításorientált terminológia területén a terminusok, funkcionális ekvivalensek vagy terminusjelöltek státuszának jelölése, a kontextus és a kollokációk, a bevett kifejezések megadása vagy a nyelvpolitikai irányzaton belül a kontrasztív fogalmi összevetés (lásd bistro jogi fogalmak). Léteznek ugyanakkor bizonyos nyelvek esetében kifejezetten szükséges adatok (például német esetében a névelők) vagy a tárgykör igényeinek függő adatok (orvosi vagy műszaki területen a képi, multimédiás információk).

A felépítésben az adatmező-kategóriák megjelenítése, az adatmezőben szereplő mennyisége is különbözhet, illetve elrejthető bizonyos karakterszám felett a szöveg egy része, amely kattintásra jelenik (lásd bistro). Ez megkönnyítheti a bejegyzések áttekinthetőségét.

A mezostruktúra szintjén az utalási rendszer vizsgálható, azaz a belső linkek (a bejegyzéseken belüli linkek, a bejegyzések közötti linkek) és a külső linkek (egyéb webhelyre mutató linkek) megléte és megjelenítési módja. A belső linkek, azaz a bejegyzéseken belüli és a további bejegyzésekre mutató linkek használata a belső utalási rendszer részét képezik, ami más formában, például fogalmi hálók létrehozatalával is megoldható. A külső linkek megjelenítése eltérhet egymástól: megnyitható-e, van-e leírás a tartalmáról (cím, útvonal), milyen típusú külső, állandó vagy eseti linkek használata megengedett (például Google képek, IATE esetében EURLEX, WIPO Pearl esetében Patentscope).

\subsection{Az adatbázis használatáról szóló információk}

A használatról szóló információkon belül vizsgálható az adatbázis kezelhetősége, felhasználóbarát jellege, az adatok megbízhatósága, frissítése, az adatbázis innovatív jellege és annak társadalmi haszna és szakmai jelentősége.

A felhasználó mindig szívesebben nyúl egy olyan eszközhöz, amely számára könnyen kezelhető, átlátható és gyorsan szolgáltat számára információkat. $\mathrm{Az}$ adatbázis kezelhetősége, felhasználóbarát jellege, amelynek a különböző futtatási platformokon is érvényesülnie kell (lásd technikai paraméterek alatt), ebből a szempontból nagy jelentőségű. A közérthetőség érdekében érdemes a rövidítéseket kerülni (például ez volt az egyik legjelentősebb úítás a Termdat jelenlegi és korábbi változata között), fontos a könnyü kereshetőség biztosítása és a megfelelő vizuális elemek használata. Szintén a vizualitás egyik szempontja az adatok megbízhatóságának egyszerü jelölési formája, hiszen hasznos, ha a felhasználó rögtön információval rendelkezik az adatok frissítéséről (rendszeresség, naprakészség). Ez utóbbi összefügg az adatok megbízhatóságával is és a terminológiai adatbázisok minőségével. A minőség megítéléséhez a bejegyzésekben a végeredmény látható, és nem minden esetben egyértelmü, hogy va- 
lóban ellenőrzött, validált adatokról van-e szó. Éppen ezért például az IATE esetében megbízhatósági csillagok, a bistro esetében ötös skála használata tájékoztat, ahol a legfelső szintet a szabványosított terminusok képviselik; a WIPO Pearl négyes kategorizálással él.

A megbízhatóságot növelendő fontos a források kiválasztása és megfelelő dokumentálása (például közösségi oldalak kerülése, DOI-azonosítóval ellátott írások mint források preferálása).

Szintén az adatok megbízhatóságához kapcsolódik, hogy milyen szerkesztési módszereket és lehetőségeket alkalmaznak az adott terminológiai adatbázis építéséhez (például szervezeti, belső és külső szakértők, közösségi szerkesztés, egyéni javaslatok leadására biztosít-e lehetőséget). Például az SAPTerm esetében országonként törekednek szakértői hálózat kiépítésére (Tamás 2015), illetve léteznek-e projektjeik egyetemi képzőhelyekkel (lásd IATE és WIPO Pearl). A szerkesztés történhet továbbá egy központi helyen vagy lokálisan és utána a központi adatbázisba betöltve (IATE és az EU fordítószolgálatai, Termdat esetében a központ és kantonok szerint, UNTERM esetében az ENSZ szerveinek adatai). Ez utóbbi esetben gondot jelenthet a duplikátumok kiszürése (lásd IATE, UNTERM).

Löckinger (2019: 9) az információk kutatási módszereit vizsgálta dokumentumszerkesztők esetében. Online kérdőivek eredményei alapján arra a megállapításra jutott, hogy a felhasználók a minőséget elsősorban a tartalom (naprakészség, szakértelem) és a használhatóság (könnyü kezelhetőség, információk közlési és besorolási módja) alapján ítélik meg.

Az adatbázis innovatív jellege összefügghet esetleg egy újszerü megjelenítési mód alkalmazásával vagy plusz ismeretelemekkel (fogalmi háló, szövegkorpusz, oktatófilm, e-kurzus) vagy adatállományok összekapcsolásával (például Google képek, IATE esetében EURLEX, WIPO Pearl esetében Patentscope).

Végül a terminológiai adatbázisok társadalmi hasznáról és szakmai jelentőségéről is érdemes szót ejtenünk. Fontos kérdés, hogy mennyire hasznosítható a terminológiai adatbázis a különböző szakmai csoportok számára, van-e nyelvés terminológiapolitikai haszna, kínál-e továbbképzési lehetőségeket, e-kurzust, tréninget, workshopot és bedolgozást a terminológiai adatbázis előállítója (pl. Termdat, IATE, WIPO).

\section{Az IATE adatbázis elemzése}

Az IATE (Interactive Terminology of Europe) az Európai Unió Intézményi Terminológiai adatbázisa úgy jött létre, hogy az uniós intézmények 1999-ben úgy döntöttek, hogy egyesítik az addig külön tárolt adatállományaikat. 2004ben nyilvános lett, majd IATE 2 néven 2018 novemberében külsőségekben és tartalmában is megújulva vált a felület elérhetővé a nagyközönség számára. Elödei közé tartozik többet közt az Európai Bizottság korábbi közismert EURODICAUTOM terminológiai adatbázisa.

Elsősorban fordítói terminológiai adatbázisról van szó, amely az uniós terminológusok munkáját hivatott támogatni. Fischer (2008) leírja azt a folyama- 
tot, melynek eredményeképpen a fordítói megoldások beépülnek az adatbázisba. Az adatbázisban szereplő adatok mérvadók az uniós fordítások készítésekor, az újonnan megjelenő terminusok esetében rögzítési kötelezettség áll fenn. A IATE külső felülete saját fejlesztésü, létezik egy nyilvános és egy belső felülete, viszont a fordítók számára jó hír, hogy adatainak része letölthető (https:// iate.europa.eu/download-iate).

$\mathrm{Az}$ adatbázis az onomasziológiai szemléletmódot a terminusautonómiát betartva tükrözi, felépítését és az adatmezők számát, az adatok kidolgozottságát tekintve hagyományos felépítésư. Megastruktúráját tekintve már a nyitó oldalon részletes adatokat szolgáltat a heti keresések, a terminusok, a bejegyzések, a módosítások számáról. Találunk továbbá információkat az adatbázis hátteréről, a létrejöttéről, a gyakran ismételt kérdésekről, a jogi nyilatkozatról (szerzői jog), a szerkesztők elérhetőségéről. Közvetlen utalás nem szerepel viszont az IATE kézikönyvről, amely egy másik oldalon online elérhető (https://iate.cdt. europa.eu/iatenew/handbook.pdf). Jelenleg az adatbázis 7,9 millió terminust tartalmaz 24 modern és latin nyelven.

A makrostruktúrát tekintve lehetőséget nyújt egyszerű és összetett keresésre, ugyanakkor a nyelvfelismerés nem megoldott, a nyelvek kiválasztása továbbra is szükséges, a keresési módozatok azonban elmenthetők. A találati lista tárgykörönként jelöli a keresés eredményét, továbbá ikonok formájában adatot szolgáltat a bejegyzés adattípusairól (pl. definíció megléte). A mikrostruktúra szintjén az adatmezőkategóriák a következők: fogalmi azonosítókód, definíció, definíció forrása, származási ország, kereszthivatkozások, terminus, terminus forrása, megbízhatóság, megjegyzés, kontextus, kontextus forrása, szerkesztő intézmény megnevezése. Megengedett a definíció kontextussal való behelyettesítése. Lesznyák (2010) tanulmányából kiderül, hogy a IATE esetében is ugyanaz a három szintből álló, hierarchikus szerkesztési struktúra él, amely megfelel a bevált gyakorlatnak és a legtöbb adatbázis-kezelő szoftver is tartalmaz (lásd SDL Multiterm és Memoq). A mezostruktúra belső és külső linkeket egyaránt tartalmaz.

A megújult adatbázis könnyen kezelhető, vizualizációs felülete felhasználóbarát. A találati lista ikonjaira ráállva felirat jelenik meg. Az adatok rendszeresen frissülnek, amiről a nyitó oldalon statisztikai adatokat láthatunk, illetve a források alatt szerepelnek szerkesztési dátumok. A dokumentáció részét képezik a megbízhatósági csillagok. Az uniós intézmények lehetőséget biztosítanak az egyetemi hallgatókkal való együttmüködésre, és annak eredményeiről referenciát adnak. Az IATE adataival mindenképpen fontos forrását és eszközét képezi a tagállamok nyelv- és terminológiapolitikai céljainak megvalósításában.

\section{A szempontrendszer hasznosíthatósága, összegzés}

A terminológiai adatbázisokra kidolgozott kritériumrendszer négy fő kategóriára épül rá:

- háttérinformációk,

- technikai paraméterek, 
- tartalmi információk és

- használatról szóló információk.

Az általunk bemutatott kísérleti jellegű vizsgálati szempontrendszer jól tükrözi, hogy a terminológiai szemléletmód és elvek viszonylag egységes megléte mellett, a terminológia segédeszközeként használt terminológiai adatbázisok jellemzői mennyire széles skálán mozognak, a domének, az irányzatok a felhasználói igényekkel összhangban más-más szerkesztési szempontokat helyeznek előtérbe. Ráadásul az egyes szempontok szorosan összefüggnek egymással, nem mindig különíthetők el egymástól egyértelműen (pl. szerkesztési elvek, dokumentáció, megbízhatóság, minőség). Kétféle nehézségbe botlottunk: egyrészt kevésbé megragadhatók a közös jellemzők, mint a szótáraknál, másfelől egy-egy szempont több helyre is besorolható.

Ezzel együtt azt gondoljuk, hogy az oktatásban, recenziók készítésekor és a fordítók számára a kidolgozott szempontrendszer segít ezen eszközök alaposabb megismerésében és tudatos használatában. A szempontrendszer lépésről lépésre történő alkalmazásával egy eszköznek akár új funkciói is felfedezhetők. Segít abban is, hogy objektív szakmai véleményt lehessen kialakítani és közölni a terminológiai adatbázisokról, akár szóbeli, akár recenzió formájában. Ahogyan azt írásunk elején hangsúlyoztuk, a szempontrendszerünk kísérleti jellegü. Maga a műfaj eleve szorosan összefügg a gyakorlati igényekkel, ugyanakkor kreativitásra is lehetőséget biztosít. Reményeink szerint átfogó jellegével e szempontrendszer akár még fejlesztési ötleteket inspirálhat.

\section{Irodalom}

Arntz, R., Picht, H., Mayer, F. 2009. Einfuhrung in die Terminolgiearbeit. Hildesheim, Zürich, New York: Georg Olms Verlag. (6. Aufl.).

Arntz, R., Picht, H., Schmitz, K-D. 2014. Einführung in die Terminologiearbeit. Hildesheim/Zürich/New York: Georg Olms Verlag.

Bessé, B., Nkwenti-Azeh, B., Sager, J. C. 1997. Glossary of terms used in terminology. In: Terminology, Vol. 4. No. 1. 117-156.

Bowker, L. 2015. Terminology and translation. In: Kocker, H.J., Steurs, F. (eds.) Handbook of Terminology. Amsterdam/Philadelphia: John Benjamins Publishing Company. 304-323.

Drewer, P., Pulitano, D., Schmitz, K-D. 2014. Terminologiearbeit. Best Practices 2.0. Köln: Deutscher Terminologie-Tag e.V.

Fischer M. 2008. Az európai uniós fordítás és terminusalkotás magyar vonatkozásai. Magyar Nyelvör 131. évf. 4. szám 385-402.

Fóris Á. 2005. Hat terminológia lecke. Pécs: Lexikográfia Kiadó.

Fóris Á. 2018. Lexikológiai és lexikográfiai ismeretek magyar (mint idegen nyelv) tanárok$n a k$. Károli Gáspár Református Egyetem. Magyarnyelv-tanári segédkönyvek. Budapest: L'Harmattan Kiadó.

Fóris Á., Rihmer Z. 2007. A szótárak minősítési kritériumairól. Forditástudomány IX. évf. 1. szám. 109-113.

Gaál P. 2012. Szempontrendszer online szótárak minősítéséhez. Magyar Terminológia 5. évf. 2. szám. 225-250. 
Lesznyák. Á. 2010. Az európa uniós intézmények terminológiai adatbázisa: A IATE. Magyar terminológia 3. évf..2. szám. 161-181.

Löckinger, G. 2019. Fachsprachliche Nachschlagewerke für technische Redakteurinnen und Redakteure - Ergebnisse einer emprischen Studie - eDITion. 15. Jahrgang, 1. Ausgabe. 5-9.

Novák 2013. A bolzanói bistro olasz-német-ladin jogi terminológiai információs rendszer bemutatása. Magyar Terminológia 6. évf. 1. szám. 61-83.

Novák 2018. A terminológiai munkafolyamat a minöségi jogalkotásban. Magyar-olasz öszszehasonlitó vizsgálat az alkotmányjogi terminológia területén. Doktori értekezés. PTE ÁJK.

Reinke, U. 2012. Terminologiearbeit fur und mit Sprachtechnologie. In: Mayer, F., Schmitz, K.-D. (Hrsg.) Terminologieprozesse und Terminologiewerkzeuge. Akten des Symposions. Heidelberg, 19-21. April 2012. Deutscher Terminologie-Tag e.V. Koln: SDK Systemdruck Koln GmbH \& Co. KG. 101-118.

Sager, J. C. 1990. A practical course in terminology processing. Amsterdam/Philadelphia: John Benjamins Publishing Company.

Schmitz, K-D., Drewer, P. 2017. Terminologiemanagement. Grundlagen, Methoden, Werkzeuge. Berlin: Springer Vieweg Verlag.

Sermann E. 2011. A terminológiai szabványosítás szerepe a lokalizáció folyamatában. Fordítástudomány. XIII. évf. 2. szám. 72-87.

Sermann E. 2019. Terminológiai adatbázisok mint a nyelvi korlátok áthidalásának eszközei. Magyar nyelven (is) elérhető néhány terminológiai adatbázis tartalmi és szerkezeti vizsgálata. ACTA HISTORIAE LITTERARUM HUNGARICARUM. ACTA UNIVERSITATIS SZEGEDIENSIS Vol. 34. No. 3. 149-169.

Sermann E., Tamás D. 2010. Hogyan definiálhatjuk a fordítói adatbázist? Egy olasz és egy spanyol fordítói terminológiai adatbázis vizsgálata. In: Károly K., Fóris Á. (szerk.) Nyelvek találkozása a fordításban. Doktori kutatások Klaudy Kinga tiszteletére. Budapest: ELTE Eötvös Kiadó. 101-115.

Sermann E., Tamás D. 2013. Elektronikus szótár vagy terminológiai adatbázis? In: Tóth Szergej (szerk.) Társadalmi változások, nyelvi változások. A XXII. MANYE Kongresszus elöadásai. Szeged 2012. április 12-14. Budapest-Szeged: MANYE-Szegedi Egyetemi Kiadó Juhász Gyula Felsőoktatási Kiadó. 450-454. (http://mek. oszk.hu/11700/11730/)

Sermann E., Tamás D. M. 2020. Vizsgálati szempontrendszer online terminológiai adatbázisokhoz. In: Fóris Á., Bölcskei A. (főszerk.) Nyelv, kultúra, identitás. Alkalmazott nyelvészeti kutatások a 21. századi információs térben. I. kötet., Budapest, Akadémiai Kiadó. (Megjelenés alatt).

Tamás D. 2010. La knowledge base EOHS Term, ossia un vocabolario online creativo. In: Dávid G. Cs., Zelényi A. (szerk.) Corvinus nyelvi napok, "Kreativitás és nyelv". 2009. szeptember 23-24. Budapesti Corvinus Egyetem IOK Alkalmazott Nyelvészeti Kutató- és Továbbképző Központ. Budapest: Aula Kiadó. 349-355.

Tamás D. 2013. Az olaszországi Bolzano autonóm megyében élő kisebbségek jogainak védelméről és a bistro terminológiai projekt létrejöttének hátteréről. Magyar Terminológia 6. évf. 1. szám. 41-60.

Tamás D. M. 2014. A gazdasági szakszövegek forditásának terminológiai kérdéseiről. Fordítástudományi értekezések I. Budapest: ELTE BTK Fordító- és Tolmácsképző Tanszék.

Tamás D. M. 2015. Az SAPterm terminológiai adatbázis vizsgálata. In: Károly K., Fóris Á. (szerk.) A forditás titkos ösvényein. Doktori kutatások Klaudy Kinga 
tiszteletére II. Budapest: ELTE Eötvös Kiadó. 211-230. (http://wwww.eltereader.hu/ media/2018/05/A_forditas_titkos_osvenyein_READER.pdf).

Tamás D. M. 2018. Miért rögzítsünk jogi szakszavakat terminológiai adatbázisokban? Magyar fogi Nyelv. II. évf. 2. szám. 30-32. (https://joginyelv.hu/beszamolo-a-joges-terminologia-cimu-konferenciarol/).

Tamás D. M. 2019a. A IUSTerm jogi és közigazgatási terminológiai adatbázis háttérmunkálatainak tapasztalatairól. In: Szoták Sz. (szerk.) Diszciplínák találkozása nyelvi közvetités a XXI. században. Budapest: OFFI Zrt. 260-281. (https://150.offi. hu/kiadvanyok/diszciplinak-talalkozasa-nyelvi-kozvetites-21-szazadban).

Tamás D. M. 2019b. A terminológiai adatbázisok mint a terminológia-stratégia eszközei. In: Fóris Á., Bőlcskei A. (szerk.) Terminológiastratégiai kihívások a magyar nyelvterületen. Budapest: OFFI-L'Harmattan. 105-119.

Tamás D. M., Sermann E., 2019. Evaluation system for online terminological databases. Terminologija No. 26., (Megjelenés alatt).

\section{Források}

\section{Elektronikus források}

http://www.eurac.edu/en/research/autonomies/commul/Pages/default.aspx (Utolsó letöltés: 2019. augusztus 5.)

https://www.wipo.int/reference/en/wipopearl/news/2019/news_0003.html (Utolsó letöltés: 2019. március 14.)

\section{Terminológiai adatbázisok}

bistro http://bistrosearch.eurac.edu/ (Utolsó letöltés: 2019. március 14.)

DINTerm https://www.din.de (Utolsó letöltés: 2019. március 14.)

Cercaterm https://www.termcat.cat/ca/cercaterm (Utolsó letöltés: 2019. augusztus 6.)

Evronim http://prevodjenje.mei.gov.rs/evronim/index.php?jezik=engl (Utolsó letöltés: 2019. augusztus 5.)

eohsterm www.eohsterm.org (Utolsó letöltés: 2019. március 14.)

EUROTERMBANK (https://www.eurotermbank.com/) (Utolsó letöltés: 2019. augusztus 5.)

EUSKALTERM(http://www.euskadi.eus/web01-apeuskal/eu/q91EusTermWar/kontsultaJSP/q91aAction.do) (Utolsó letöltés: 2019. augusztus 5.)

France Terme (http://www.culture.fr/franceterme) (Utolsó letöltés: 2019. augusztus 5.)

IATE https://iate.europa.eu; https://iate.europa.eu/home (Utolsó letöltés: 2019. március 14.)

SAPTerm www.sapterm.com (Utolsó letöltés: 2019. március 16.)

Termdat www.termdat.ch (Utolsó letöltés: 2019. március 15.)

Termium Plus https://www.btb.termiumplus.gc.ca (Utolsó letöltés: 2019. március 14.)

Verwaltungsglossar https://www.sprachressourcen.at/verwaltungsglossar/ (Utolsó letöltés: 2019. augusztus 5.)

WIPO Pearl https://www.wipo.int (Utolsó letöltés: 2019. március 15.)

Termin https://jogi-terminologia.im.gov.hu/ (Utolsó letöltés: 2019. március 14.)

UNTERM (http://untermportal.un.org) (Utolsó letöltés: 2019. augusztus 5.) 


\section{Függelék}

Vizsgálati szempontrendszer online terminológiai adatbázisokhoz

\section{A központi terminológiai adatbázissal kapcsolatos háttér-információk}

A) Tágabb háttér

1. Az adott domén fellelhető terminológiai adatbázisainak áttekintése:

- történeti előzmények, korábbi változatok, továbbfejlesztett adatbázis

- diakrón és/vagy szinkrón leírás;

- kapcsolat más terminológiai adatbázisokkal szervezeten belül és kívül;

2. Irányzatok szerinti besorolás:

- nyelvpolitikai célok megvalósítása

- fordítói/fordításorientált terminológiai adatbázis

- szabványosító

B) Szükebb háttér

1. A terminológiai adatbázis-előállító jellemzői:

- a szervezet háttere, országos vagy nemzetközi érdekeltség, szakterület, anyagi források, a szervezet típusa (nemzetközi szervezet, közigazgatási szervezet, kutatóintézet, egyetem, fordítóiroda)

2. Célcsoport:

- anyanyelvi beszélők számára, többségi vagy kisebbségi státuszú nyelvhasználók

- fordítók

- adott szakma képviselöi, pl. mérnök, jogász, orvos stb.

3. Felhasználási cél:

- leíró jelleg

- elő́ró jelleg

\section{A terminológiai adatbázis technikai paraméterei}

A) A szoftver jellege:

- saját fejlesztésú

- hibrid

- forgalmazott szoftver

B) A terminológiai adatbázis hozzáférhetősége

- nyilvános vagy korlátozottan hozzáférhető

- adatok letölthetősége, futtatási plattformok (pl. okostelefon, tablet/táblagép) 


\section{A terminológiai adatbázis tartalmáról szóló információk}

A) Az adatbázis föláltalános jellemzöi

1. Fogalomközpontúság

- kizárólag onomasziológiai szemléletet tükröző

- szemasziológiai elemeket is tartalmazó hibrid jellegú

2. Egyszerü, hagyományos vagy összetett

- a szerkezeti egységek száma (fogalmi háló vagy szövegkorpusz)

- a bejegyzések kifejtettsége: adatmező-kategóriák típusa és száma

B) Az adatbázis szerkezete részletes jellemzöi

1. Megastruktúra

- használati útmutató és egyéb segédletek: fórum, chat-szolgáltatás elakadás esetén (pl. lásd SAPTerm: chat, SAP Community, SAP Help Portal)

- szerzői jogi/adatvédelmi információk fellelhetősége (pl. IATE)

- információk a fogalmak/bejegyzések és a terminusok számáról

- nyelvek száma (egy-, két- vagy többnyelvü)

- domének és aldomének száma

- terminusok száma

2. Makrostruktúra

- a keresés módjai (egyszerü, összetett - terminusok szerint, domén szerint, szórészlet - SAPTerm, a nyelvi keresés mellett fogalmi háló alapján -vagy szövegkorpuszban; link révén átjárás más adatállományba)

- a keresési találatok megjelenítése módja, rendezettsége (találati lista van vagy nincs)

- a közölt anyag jellege (szöveges, képi, multimédiás információk)

3. Mikrostruktúra

- az adatmező-kategóriák száma: kidolgozás részletessége

- az adatmező-kategóriák típusai:

- kötelező és fakultatív adatmezők (definíció és/vagy kontextus);

- adatmező-típusok összhangban vannak-e a szerkesztési elvekkel a szakirodalom, ISO, bevált gyakorlat és minták alapján (pl. hierarchikus elrendezési mód - entry/language és term level);

- a terminológiai adatmodellálás elveinek betartása: fogalomközpontúságon túl a terminusautonómia, a hierarchikus szerkesztési mód, az elementaritás és a granularitás;

- adatmezőtípusok a munkamódszer szerint: definíció megléte vagy hiánya; definíció hány nyelven szerepel; egy fogalmat mutat be a definíció vagy kontrasztív egybevetés a cél;

- adatmezőtípusok az irányzatok szerint: szabványosítás, fordítói vagy nyelvpolitikai célok;

- adatmezőtípusok a tárgykörök igényei szerint (pl. müszaki: ábra);

- az adatmező-kategóriák megjelenítése és a bejegyzések áttekinthetősége: az adatmező-kategóriák megjelenítésének sorrendje és megnevezése 
4. Mezostruktúra

- belső linkek (a bejegyzéseken belüli linkek, a bejegyzések közötti linkek)

- külső linkek (egyéb webhelyre mutató linkek)

- linkek megjelenítési módja (megnyitható link, elérhetőség, tartalom leírása)

\section{A terminológiai adatbázis használatáról szóló információk}

A) Az adatbázis kezelhetősége, felhasználóbarát jellege

- közérthetőség

- rövidítések rendszere

- vizuális elemek

• könnyü kereshetőség

B) Az adatok frissitése

- rendszeresség

- naprakészség

C) Az adatok megbizhatósága

- dokumentáció: az erről szóló információk megjelenítése az egyes bejegyzéseknél, annak jelölési formája (megbízhatóság jelölése csillaggal, ikonnal, szöveggel);

- szerkesztési lehetőségek (szervezeti, közösségi szerkesztés, egyéni javaslatok leadására biztosít-e lehetőséget)

D) Az adatbázis innovatív jellege

- plusz ismeretelemeket tartalmaz (fogalmi háló, szövegkorpusz, oktatófilm, e-kurzus)

- megjelenítési módja újszerü vagy sem

E) Az adatbázis társadalmi haszna és szakmai fontossága

- szakemberek köre és típusa

- nyelvstratégiai szempontok érvényesülése

- kínál-e továbbképzési lehetőségeket, e-kurzust, tréninget, workshopot és bedolgozást a terminológiai adatbázis előállítója 